\title{
Article \\ The First Data on Parasitic Arthropods of the European Bison in the Summer Season with a World Checklist
}

\author{
Joanna N. Izdebska ${ }^{1, *} \mathbb{1}$, Leszek Rolbiecki ${ }^{1}\left[\right.$ and Wojciech Bielecki ${ }^{2}$ \\ 1 Department of Invertebrate Zoology and Parasitology, Faculty of Biology, University of Gdańsk, Wita Stwosza 59, \\ 80-308 Gdańsk, Poland; leszek.rolbiecki@ug.edu.pl \\ 2 Division of Avian Diseases, Exotic Animals and Fish, Department of Pathology and Veterinary Diagnostics, \\ Institute of Veterinary Medicine, Warsaw University of Life Sciences, Ciszewskiego 8, 02-786 Warsaw, Poland; \\ wojciech_bielecki@sggw.edu.pl \\ * Correspondence: biojni@ug.edu.pl
}

check for updates

Citation: Izdebska, J.N.; Rolbiecki, L.; Bielecki, W. The First Data on Parasitic Arthropods of the European Bison in the Summer Season with a World Checklist. Diversity 2022, 14, 75. https://doi.org/10.3390/ d14020075

Academic Editor: Luc Legal

Received: 19 December 2021

Accepted: 18 January 2022

Published: 22 January 2022

Publisher's Note: MDPI stays neutral with regard to jurisdictional claims in published maps and institutional affiliations.

Copyright: (C) 2022 by the authors. Licensee MDPI, Basel, Switzerland. This article is an open access article distributed under the terms and conditions of the Creative Commons Attribution (CC BY) license (https:// creativecommons.org/licenses/by/ $4.0 /)$.

\begin{abstract}
The European bison (wisent) Bison bonasus is not only the largest terrestrial mammal in Europe, but also an example of the successful restitution and reintroduction of a species that became extinct in nature at the beginning of the 20th century. Even so, it remains a rare, protected species, and one susceptible to varied threats, including diseases. It has a specific parasitofauna, comprising only a few specific species retained with the last hosts in the restitution process, and some others acquired from other ungulates, or via environmental interactions. The current data on parasitic arthropods originated from the winter season, and less frequently, from autumn and early spring. The present study contains the first information on the occurrence of arthropods in the European bison $(n=6)$ in the summer season, which is the period of their increased activity. Data on the seasonal and populational dynamics of ectoparasites have been verified; specific parasite species (Demodex bisonianus, Bisonicola sedecimdecembrii, and recently described Demodex bialoviensis) and typical parasite species (Chorioptes bovis, Ixodes ricinus) have been recorded. The data refer to the information from other study periods, summarizing and valorizing data on parasitic arthropods in the form of a global checklist. These arthropods occur in European bison frequently (prevalence reaches up to $100 \%$ ), but they are present in small numbers, and do not present a burden for the host; only sometimes, with high intensity of infection, they cause parasitoses (chorioptosis, mallohagosis). However, as an effect of regular activity, by penetrating the skin of the host, they create gateways for secondary infections, and hematophagous parasites (e.g., ticks) can be vectors of pathogens that can be hazardous, even at low infection levels. The identification of the parasitological threats faced by European bison is not only important from the standpoint of the study object, i.e., the Białowieża Forest European bison population, from which the existing bison population of Europe has been derived, but also the fact that their transfer to different parts of Europe can entail the additional transfer of their parasites.
\end{abstract}

Keywords: Acari; checklist; ectoparasites; Insecta; parasites; wild ungulates; wisent

\section{Introduction}

The European bison (wisent) Bison bonasus Linnaeus, 1758, is a unique object of parasitological study. It is not only a rare and endangered animal, but it is also Europe's largest mammal, and a relic species of the Pleistocene megafauna. Natural populations of the European bison became extinct at the beginning of the 20th century, and the current wild populations are the result of a successful species restitution based on the individuals that survived in breeding facilities. As a consequence, with the last representatives of the species, few specific (monoxenic) parasites survived, and the current parasitofauna (89 recorded species) originates from other ungulates [1,2]. Of the global population, $25 \%$ are found in Poland, and close to $10 \%$ in the Polish part of the Białowieża Forest population, currently comprising approx. 800 individuals [3,4]; in addition, as the Białowieża population served 
as the origin of all modern populations, it constitutes a reliable model for parasitological analyses for this species, particularly for specific and typical parasites.

The existing data on parasitic arthropods mainly originate from Poland. Comprehensive studies covering approx. 400 individuals have been conducted there since the 1990s. Although most studies were performed in the Białowieża Forest, others have included other wild herds, breeding centers, and zoological gardens ([5-9], Izdebska unpublished data). A total of 15 parasitic arthropods have been recorded as being associated with European bison, with the host status ranging from specific, to typical, sporadically, and accidental. However, as the European bison is a rare species, covered by various statuses and conservation laws, test material is not easily accessible; all preceding data originated from the winter season, late autumn and early spring, and no data are available for the summer season. The presented paper contains the first published information from this period, i.e., from July; it verifies earlier hypotheses concerning the species composition and dynamics of occurrence of parasitic arthropods observed during other seasons.

The arthropods parasitising European bison may not only be a cause of various parasitosis in the host, but by damaging and penetrating the skin, they create the gates for secondary infections, also fulfilling the role of pathogen vectors. Therefore, the study provides a more extensive image of the ectoparasitofauna and the seasonal dynamics of infestation by individual species; it also provides a greater insight into the associated hematophages, which are particularly predisposed to the role of pathogen vectors.

The active protection of the European bison requires the constant monitoring of threats, including parasitological ones. However, as a result of the protective measures, wisents have been moved to new herds or to centers in different parts of Europe, including Spain, France, Sweden, Denmark, Bulgaria, and the Czech Republic [10], and such transfers can also bring with them new parasites which may be alien to the native mammals and other fauna.

\section{Materials and Methods}

\subsection{Detection of Parasitic Arthropods in Bison bonasus}

Following elimination, six European bison from the Białowieża Forest were examined for the presence of parasitic arthropods in July 2011. All hosts were tested immediately after death. In order to confirm the presence of ectoparasites (Phthiraptera, Ixodida), $5 \mathrm{~cm}$ strips of fur were investigated; any parasitic arthropods found there were fixed in $70 \%$ ethanol, and some were mounted in polyvinyl-lactophenol [11]. In addition, skin mites (Demodecidae, Psoroptidae, Sarcoptidae) were isolated using skin digestion methods [12], with modifications to suit the examined host. Skin fragments of $3 \mathrm{~cm}^{2}$ were examined from several body regions, including the head (around the eyes, nose, area of vibrissae, lips, chin, cheeks, vertex), neck, abdomen, back, limbs, and genital-anal area. Skin samples were preserved in $70 \%$ ethanol and digested in $10 \% \mathrm{KOH}$ solution; the obtained samples were decanted and examined using phase-contrast microscopy. Any recovered skin mites were also placed in polyvinyl-lactophenol solution and subjected to morphometric examination (measurements in micrometers). In addition, in the case of skin lesions, scrapings were collected and analyzed. The applied decanting method also made it possible to collect microscopic Ixodes larvae located deep in the skin.

When identifying arthropods, original descriptions and redescriptions of species were used, based on morphological features, as well as comparative materials from the Collection of Extant Invertebrates in Department of Invertebrate Zoology and Parasitology, University of Gdańsk, Poland (UGDIZP), and characteristics from detailed monographs [13-15].

The voucher specimens were deposited in scientific collections within the UGDIZP scientific collection.

The scientific and common names of the hosts follow Wilson and Reeder [16] and the Integrated Taxonomic Information System [17].

The prevalence, intensity, and density were calculated to determine the level of host infection [18]. 


\subsection{The Checklist Structure}

A checklist was drawn up based on publications published in the period 1927-2021. The parasites are listed in systematic order, and in alphabetical order within the genera. The list further includes information on the host specificity and localities of infected European bison. It also contains own unpublished data, marked in the list as "this study".

\section{Results}

\subsection{Parasitic Arthropods in Bison bonasus in the Summer Season}

The present study confirms the occurrence of parasitic arthropods found earlier in European bison: the mites Demodex bisonianus, Chorioptes bovis, Ixodes ricinus, Psoroptes equi, and Sarcoptes scabiei, and the insect Bisonicola sedecimdecembrii. Moreover, examples of Demodex were found; these were identified as a new species and described as D. bialoviensis [19] (Table 1).

Table 1. List of parasitic arthropods in European bison according to basis infection parameters.

\begin{tabular}{cccccc}
\hline Species & $\begin{array}{c}\text { Number of } \\
\text { Infected Hosts }\end{array}$ & $\begin{array}{c}\text { Number of } \\
\text { Parasites }\end{array}$ & Prevalence (\%) & Mean Intensity & $\begin{array}{c}\text { Density } \mathbf{1} \\
\left(\mathbf{p e r} \mathbf{1} \mathbf{c m}^{\mathbf{2}}\right)\end{array}$ \\
\hline Ixodes ricinus & 6 & $672^{2}$ & 100.0 & 112 & - \\
\hline Demodex bialoviensis & 2 & $50^{3}$ & 33.3 & - & - \\
\hline Demodex bisonianus & 6 & $119^{3}$ & 100.0 & - & - \\
\hline Chorioptes bovis & 5 & $2880^{3}$ & 83.3 & 1.9 \\
\hline Psoroptes equi & 1 & $3^{3}$ & 16.7 & - & 0.8 \\
\hline Sarcoptes scabiei & 1 & $1^{3}$ & 16.7 & 6.3 \\
\hline Bisonicola sedecimdecembrii & 1 & $6^{2}$ & 16.7 & - \\
\hline
\end{tabular}

${ }^{1}$ only skin mites (Ch. bovis, D. bialoviensis, D. bisonianus, P. equi, S. scabiei), ${ }^{2}$ number of parasites in the host, ${ }^{3}$ number of parasites in the examined skin fragments.

The highest infestation parameters were exhibited by the sheep tick I. ricinus, which was found in all examined European bison individuals. However, different developmental stages were recorded: females, nymphae, and larvae (Figure 1). Similarly, D. bisonianus was found in all hosts, but the infestation level was low. Choriptes bovis was recorded in five European bison individuals, D. bialoviensis in two, and Psoroptes equi, and Sarcoptes scabiei in only one (Table 1).

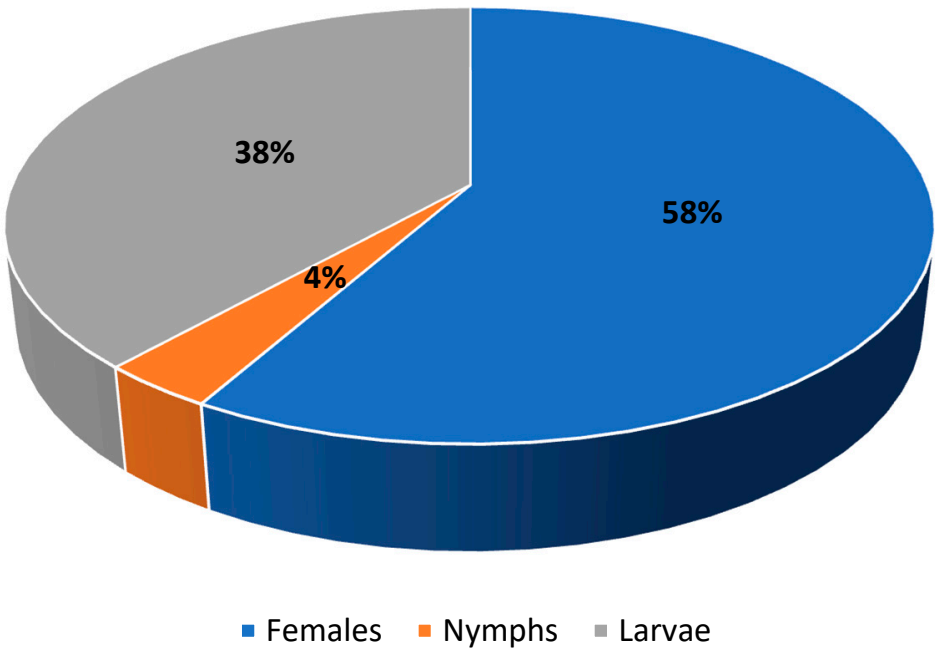

Figure 1. Population structure of Ixodes ricinus. 


\subsection{Biodiversity of Parasitic Arthropods in Bison bonasus}

Fifteen parasitic arthropods have been identified among European bison from different regions of the world: ten species of mite (four from Parasitoformes and six from Acariformes), and five species of insect (two from Phthiraptera and three from Diptera). Only three arthropods are species-specific to the European bison (Table 2).

Table 2. Parasitic arthropods associated with European bison.

\begin{tabular}{|c|c|c|c|c|}
\hline Group & Species & Locality & Remarks & Reference(s) \\
\hline \multirow[t]{4}{*}{$\begin{array}{l}\text { Acari } \\
\text { Parasitiformes, } \\
\text { Ixodidae }\end{array}$} & $\begin{array}{l}\text { Dermacentor reticulatus } \\
\quad \text { (Fabricius, 1794) }\end{array}$ & $\begin{array}{l}\text { Belarus: free-living in Białowieża } \\
\text { Forest, Lithuania: free-living and } \\
\text { in captivity, Poland: free-living } \\
\text { in Białowieża Forest and in } \\
\text { captivity (Reserve in Białowieża, } \\
\text { Niepołomice, Smardzewice) }\end{array}$ & $\begin{array}{l}\text { Typical parasite (adults) } \\
\text { of ungulates, including } \\
\text { European bison }\end{array}$ & {$[5-7,20-31]$} \\
\hline & $\begin{array}{c}\text { Ixodes hexagonus Leach, } \\
1815\end{array}$ & $\begin{array}{l}\text { Poland: in captivity } \\
\text { (Niepołomice) }\end{array}$ & $\begin{array}{l}\text { Typical parasite of small } \\
\text { mammals, accidentally } \\
\text { on the European bison }\end{array}$ & {$[6]$} \\
\hline & $\begin{array}{l}\text { Ixodes persulcatus } \\
\text { Schulze, } 1930\end{array}$ & $\begin{array}{l}\text { Poland: free-living in Białowieża } \\
\text { Forest and in captivity (Reserve } \\
\text { in Białowieża) }\end{array}$ & $\begin{array}{l}\text { Polyxenic, rare on the } \\
\text { European bison }\end{array}$ & {$[6,7,20-22]$} \\
\hline & $\begin{array}{l}\text { Ixodes ricinus } \\
\text { (Linnaeus, 1758) }\end{array}$ & $\begin{array}{l}\text { Lithuania: free-living and in } \\
\text { captivity, Poland: free-living in } \\
\text { Białowieża Forest and } \\
\text { Bieszczady Mountains, and in } \\
\text { captivity (Reserve in Białowieża, } \\
\text { Niepołomice, Smardzewice, } \\
\text { zoological gardens) }\end{array}$ & $\begin{array}{l}\text { Polyxenic, typical } \\
\text { parasite } \\
\text { of the European bison }\end{array}$ & $\begin{array}{c}{[6,7,20-22,24,25,27,28,31,32],} \\
\text { this study }\end{array}$ \\
\hline \multirow[t]{3}{*}{$\begin{array}{c}\text { Acari } \\
\text { Acariformes } \\
\text { Demodecidae }\end{array}$} & $\begin{array}{l}\text { Demodex bialoviensis } \\
\text { Izdebska, Rolbiecki et } \\
\text { Bielecki, } 2022\end{array}$ & $\begin{array}{l}\text { Poland: free-living in Białowieża } \\
\text { Forest }\end{array}$ & $\begin{array}{l}\text { Specific parasite of the } \\
\text { European bison }\end{array}$ & [19], this study \\
\hline & $\begin{array}{c}\text { Demodex bisonianus } \\
\text { Kadulski et Izdebska, } \\
1996\end{array}$ & $\begin{array}{l}\text { Poland: free-living in Białowieża } \\
\text { Forest and Bieszczady } \\
\text { Mountains, and in captivity } \\
\text { (Reserve in Białowieża, } \\
\text { Niepołomice, Smardzewice, } \\
\text { zoological gardens) }\end{array}$ & $\begin{array}{l}\text { Specific parasite of the } \\
\text { European bison }\end{array}$ & {$[6-8,19-21,32-34]$, this study } \\
\hline & $\begin{array}{l}\text { Demodex bovis Stiles, } \\
1892\end{array}$ & $\begin{array}{l}\text { Poland: in captivity (Reserve in } \\
\text { Białowieża) }\end{array}$ & $\begin{array}{l}\text { Specific parasite of cattle } \\
\text { Bos taurus Linnaeus, } \\
\text { 1758; } \\
\text { also noted in the Bos } \\
\text { taurus indicus Linnaeus, } \\
1758 \text { and accidentally in } \\
\text { the European bison }\end{array}$ & {$[6]$} \\
\hline \multirow[t]{2}{*}{$\begin{array}{l}\text { Acari } \\
\text { Acariformes } \\
\text { Psoroptidae }\end{array}$} & $\begin{array}{l}\text { Chorioptes bovis } \\
\text { (Hering, 1845) }\end{array}$ & $\begin{array}{l}\text { Poland: free-living in Białowieża } \\
\text { Forest and Bieszczady } \\
\text { Mountains, and in captivity } \\
\text { (Reserve in Białowieża, } \\
\text { Niepołomice, Smardzewice, } \\
\text { zoological gardens) }\end{array}$ & $\begin{array}{l}\text { Typical parasite of } \\
\text { ungulates }\end{array}$ & $\begin{array}{c}{[6-8,20,21,32,35,36], \text { this }} \\
\text { study }\end{array}$ \\
\hline & $\begin{array}{l}\text { Psoroptes equi }{ }^{1} \\
\text { (Hering, 1838) }\end{array}$ & $\begin{array}{l}\text { Poland: free-living in Białowieża } \\
\text { Forest and in captivity (Reserve } \\
\text { in Białowieża) }\end{array}$ & $\begin{array}{l}\text { Typical parasite of } \\
\text { ungulates, rare in the } \\
\text { European bison }\end{array}$ & {$[6-8,20,21,37]$, this study } \\
\hline $\begin{array}{l}\text { Acari } \\
\text { Acariformes } \\
\text { Sarcoptidae }\end{array}$ & $\begin{array}{l}\text { Sarcoptes scabiei } \\
\text { (De Geer, 1778) }\end{array}$ & $\begin{array}{l}\text { Poland: free-living in Białowieża } \\
\text { Forest and in captivity (Reserve } \\
\text { in Białowieża) }\end{array}$ & $\begin{array}{l}\text { Polixenic mammalian } \\
\text { parasite, rare in the } \\
\text { European bison }\end{array}$ & {$[7,8,21]$, this study } \\
\hline $\begin{array}{c}\text { Insecta } \\
\text { Pthiraptera, } \\
\text { Trichodectidae }\end{array}$ & $\begin{array}{l}\text { Bisonicola } \\
\text { sedecimdecebrii } \\
\text { (Eichler, 1946) }\end{array}$ & $\begin{array}{l}\text { Europe, Poland: free-living in } \\
\text { Białowieża Forest and } \\
\text { Bieszczady Mountains, and in } \\
\text { captivity (Reserve in Białowieża, } \\
\text { Niepołomice, Smardzewice, } \\
\text { zoological gardens) }\end{array}$ & $\begin{array}{l}\text { Specific parasite of } \\
\text { European bison }\end{array}$ & $\begin{array}{c}{[6,7,9,20,24,25,32,38-40]} \\
\text { this study }\end{array}$ \\
\hline
\end{tabular}


Table 2. Cont.

\begin{tabular}{|c|c|c|c|c|}
\hline Group & Species & Locality & Remarks & Reference(s) \\
\hline $\begin{array}{c}\text { Insecta } \\
\text { Pthiraptera, } \\
\text { Haematopinidae }\end{array}$ & $\begin{array}{l}\text { Haematopinus } \\
\text { eurysternus } \\
\text { (Nitasch, 1818) }\end{array}$ & Poland: Białowieża Forest & $\begin{array}{l}\text { Specific parasite of } \\
\text { cattle, found only once } \\
\text { on the European bison }\end{array}$ & {$[41]$} \\
\hline \multirow[t]{3}{*}{$\begin{array}{c}\text { Insecta } \\
\text { Diptera, } \\
\text { Hippoboscidae }\end{array}$} & $\begin{array}{l}\text { Hippobosca equina } \\
\text { Linnaeus, } 1758\end{array}$ & $\begin{array}{l}\text { Poland: free-living in Białowieża } \\
\text { Forest }\end{array}$ & $\begin{array}{l}\text { Typical parasite of } \\
\text { ungulates, accidentally } \\
\text { on the European bison }\end{array}$ & {$[25]$} \\
\hline & $\begin{array}{l}\text { Lipoptena cervi } \\
\text { Linnaeus, } 1758\end{array}$ & $\begin{array}{l}\text { Poland: free-living in Białowieża } \\
\text { Forest and in captivity (Reserve } \\
\text { in Białowieża, Niepołomice), } \\
\text { Ukrainian (Crimean Reserve) }\end{array}$ & $\begin{array}{l}\text { Typical parasite of } \\
\text { cervids, noted } \\
\text { sporadically on } \\
\text { European bison }\end{array}$ & {$[6,7,20,24,25,42]$} \\
\hline & $\begin{array}{l}\text { Melophagus ovinus } \\
\text { (Linnaeus, 1758) }\end{array}$ & $\begin{array}{l}\text { Poland: in captivity (Reserve in } \\
\text { Białowieża) }\end{array}$ & $\begin{array}{l}\text { Sheep-specific parasite, } \\
\text { accidentally on the } \\
\text { European bison }\end{array}$ & {$[6]$} \\
\hline
\end{tabular}

${ }^{1}$ Previously also given as P. ovis (Hering, 1838) [37].

\section{Discussion}

\subsection{Occurrence of Parasitic Arthropods in the European Bison in the Summer Season}

Despite its successful restitution and the application of various forms of conservation, the European bison remains endangered. The problems for its survival are the changes occurring in the environment in response to anthropopression, resulting most obviously in the shrinkage of its natural habitat. However, the existing bison population also suffers from a reduction of the gene pool, resulting from the restitution of the species from a small initial group; this generates a low level of heterozygosity (high level of inbreeding), and possibly lower immunity and susceptibility to diseases, including a disease of the male sexual organs (posthitis) observed in European bison from the Białowieża Forest [43-46].

It is therefore important to study the parasitofauna of European bison, especially parasitic arthropods; these can cause parasitosis. resulting from high levels of infection, particularly high intensity (parasite load), and skin damage, which creates a gateway for secondary infections. Parasites can also play the role of pathogen vectors, and as such, even singular parasites can pose a threat to the species. In the current research, conducted for the first time in the summer, parasitic arthropods were present in all examined European bison individuals (total prevalence was 100\%/6 specimens), but it is difficult to compare the infestation data for individual parasite species to those identified in previous studies, due to differences in research methodology. The ectoparasites were present on the entire body surface of the European bison; therefore, all specimens found on the host were collected. The findings were used to determine the prevalence and mean intensity of infestation for the examined bison group and the parasite load of individuals. However, the microscopic skin mites with reclusive lifestyles were detected by means of digestion and decanting [11,12], from skin cuttings originating from different areas of the body. The results provide an image of their distribution and mean population density on a skin cutting, which enables a rough estimation of the infestation prevalence, but it does not enable an accurate determination of the entire infestation intensity and parasite load. However, in the case of the Demodecidae, which exhibit a strict topical and topographical specificity, only being found in a given area of the body related to specific skin or tissue structures, these data are more precise for demodecid mite species with more limited locations. For example, D. bisonianus is only found in the eyelid area, in the Meibomian glands, while D. bialoviensis is restricted to the nasal area $[19,47]$. The low Demodecidae density observed in the present study indicates a low load for the host, and hence, an asymptomatic infestation. This is a typical image of Demodecidae infestation in wild mammals; being monoxenic parasites, demodecid mites are excellently adapted to inhabit their hosts as a result of a prolonged evolution of the host-parasite relationship. They are typically well tolerated and do not cause disease symptoms. Demodex bisonianus was described in 1996 from the Białowieża Forest, and although it was subsequently recorded in European bison from other wild and captive 
herds, no cases of demodecosis related to its presence have been recorded [8,47]. Demodex bialoviensis was described at a much later date [19] (Figure 2), which also confirms the asymptomatic nature of its infestation; no changes have been observed in many specimens of the tested wisent, neither in the present study, nor in the preceding research.

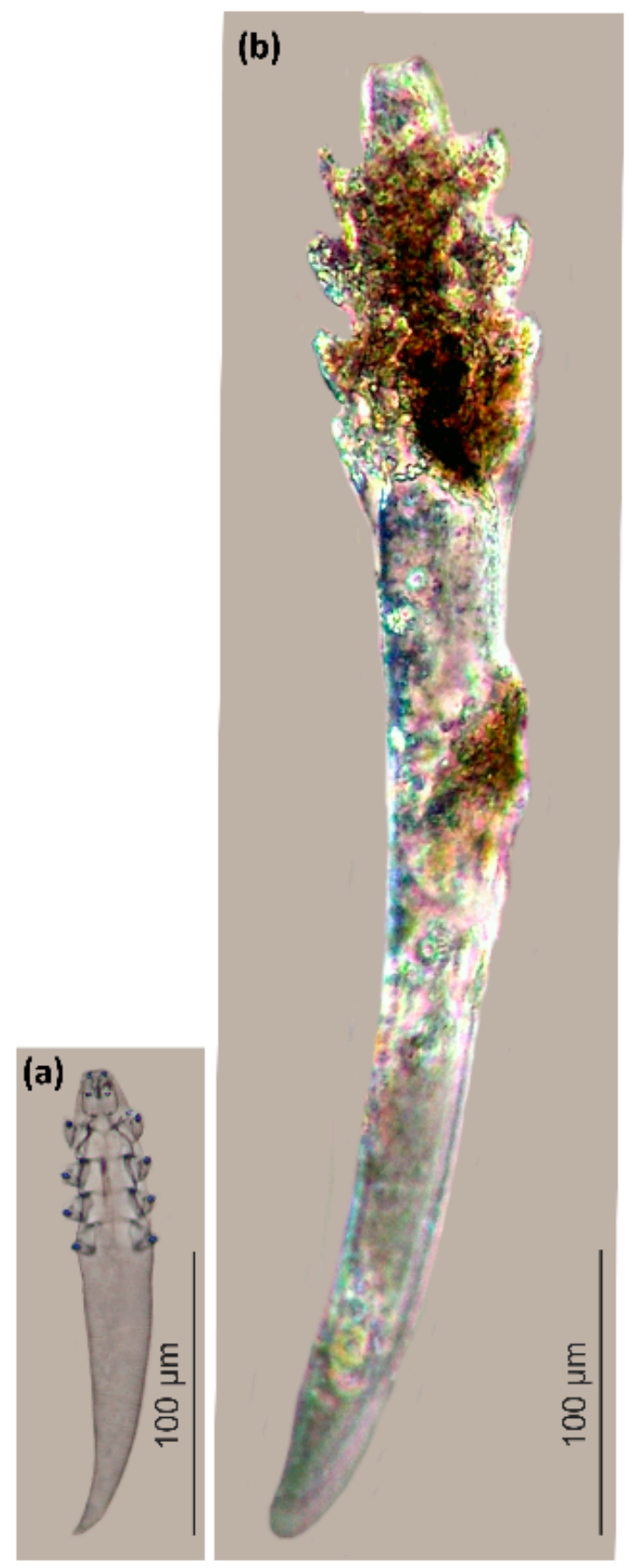

Figure 2. Demodex bialoviensis (a) and Demodex bisonianus (b), scaled.

The third identified skin mite, frequently noted for European bison, is Ch. bovis. This mite is oligoxenic, which is typical for various ungulates. It shows different topography, and prefers the posterior limb and abdominal area, but it is sometimes also found on the dorsal or neck skin $[8,36,48]$. In the summer season, a similar density was observed as in the autumn and winter season, with chorioptosis symptoms typically noted in the area of the rear limbs (Figure 3). 

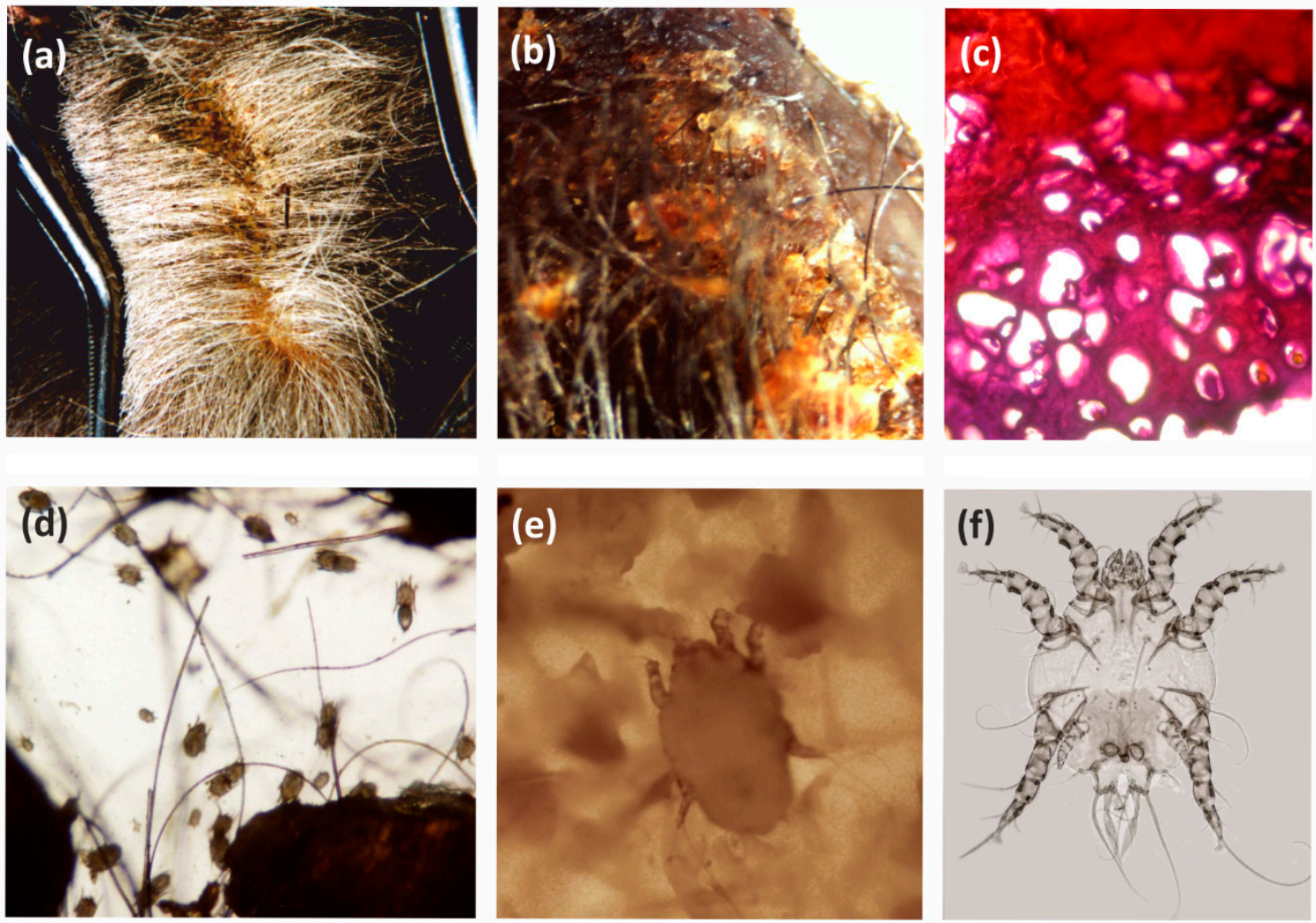

Figure 3. Chorioptes bovis and chorioptosis in the European bison: (a,b) macroscopy skin lesions; (c) histopathological changes in the skin; (d) Mites in the scrapings; (e) Female in the scrapings; (f) Male, microscope slide.

The most common parasite in the summer season was I. ricinus (Figure 4), recorded in relatively high numbers in all individual European bison. These ticks are also recorded in European bison in the remaining seasons [34], but their numbers exhibit clear seasonal dynamics characterized by periods of activity and diapause [22]. These ticks were not found to be as numerous in the European bison tested during other seasons in previous studies. Winter is typically the diapause period, and as such, they tended to be recorded singularly or in low numbers; most were females, found on the lateral part of the body, and in the abdominal area. Normally, these ticks exhibit activity from early spring to autumn, and hence, were more common between winter and spring, or in autumn [22]. Our present findings indicate that they are not only common and more numerous in summer, but also exhibit a wider topographic spectrum and different population dynamics. Adult specimens (mainly females) were recorded from different areas of the body, although it was determined that their occurrence and locality are determined by the accessibility of blood vessels, which results from gnathosoma size and host skin thickness. This correlation was confirmed by a previous comparison of tick gnathosoma measurements and skin thickness measurements from different areas of the body of the European bison and red deer Cervus elaphus Linnaeus, 1758 [49]. The topography of I. ricinus females turned out to be varied, which resulted from the limited capability to penetrate the skin by their gnathosoma; as these ticks face more limited skin penetration capabilities against European bison, they are often found locally (e.g., the hypogastrium region) but at higher concentrations. However, in contrast to other seasons, the nymphae and larvae of this species, but not the adult stages, were found to be relatively numerous (including fed individuals) in the European bison examined during the summer. This is in contrast with exiting knowledge on the three-host developmental cycle of the I. ricinus, which indicates that larvae live in small hosts (e.g., insectivores, rodents, lagomorphs, bats, birds, or reptiles); the nymphal stages prefer larger hosts (e.g., carnivorans), while the adults mainly attack large mammals $[14,50]$. This is 
determined, among other elements, by the small sizes of the juvenile stages, particularly the larvae, in which the small mouth organs restrict the skin penetration possibilities in larger hosts. However, these stages were common in the European bison observed in the summer, but they were observed in different locations to the females. They were mainly located in more secluded sites/habitats, with thicker skin and easier access to vessels, e.g., near the lips (from the gum side) in the nasal cavity and in the perianal region (Figure 4).
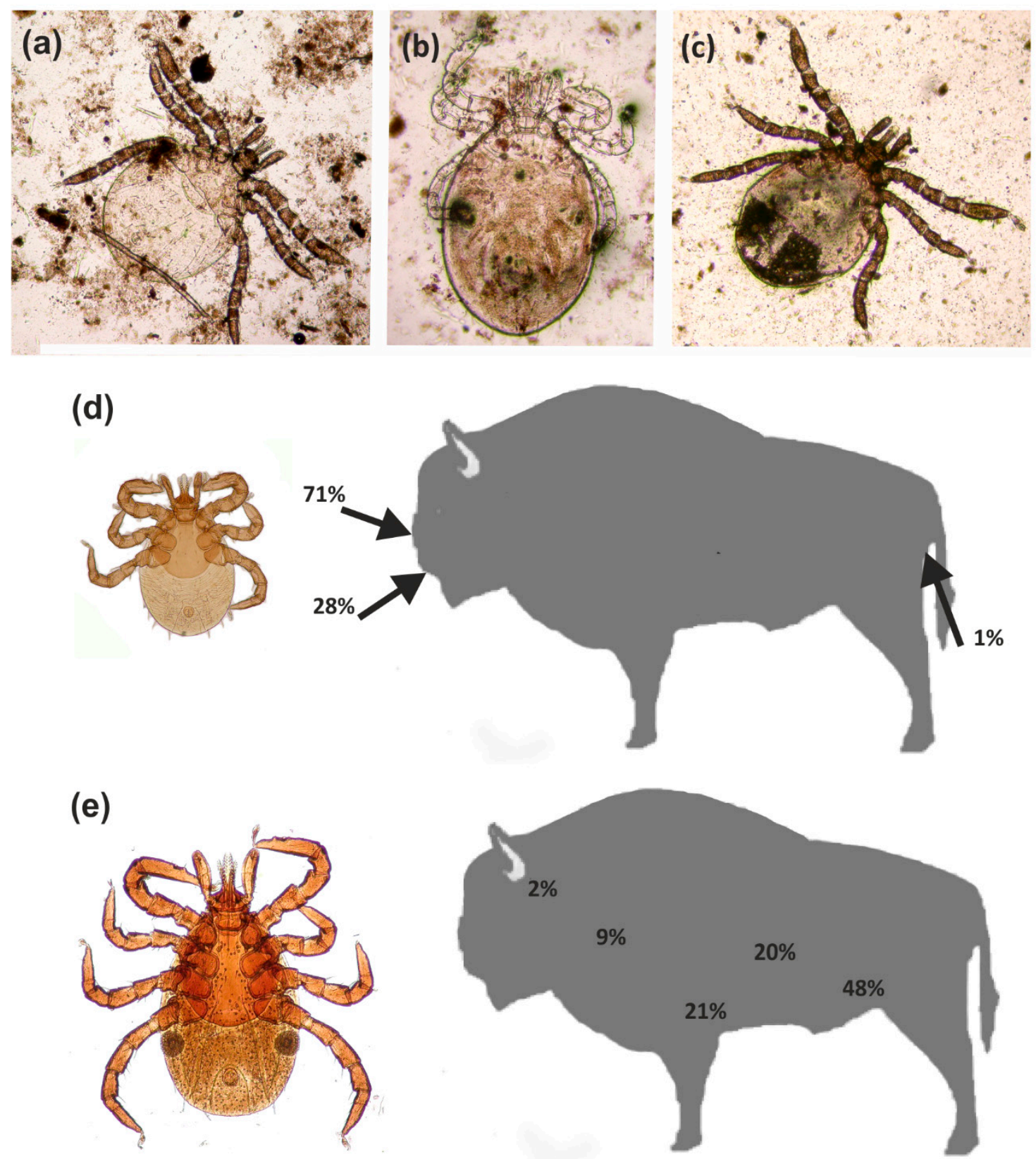

Figure 4. Ixodes ricinus: (a-c) Larvae from the nasal cavity; (d) Topography of larvae in the European bison; (e) Topography of females in the European bison.

The least common parasite found in the European bison during the summer season was the chewing louse $B$. sedecimdecembrii, whose population only comprised a small number of females. This parasite exhibits considerably higher infestation parameters in the winter season, when all developmental stages can be observed [9,38]. It is possible that winter may be the breeding period for this species; the fur cover in the European bison is 
considerably thicker during this time, particularly the down hairs, and this would provide better living conditions, and a larger food base for keratophagous parasites.

\subsection{State of Research on Parasitic Arthropods of the European Bison}

The first reports on the occurrence of parasitic arthropods from the European bison were given by Wróblewski [41]. In 1946, Eichler [39], based on a study of several museum specimens from the Białowieża Forest European bison, described a chewing louse species specific to these mammals, namely Bovicola sedecimdecembrii, which was classified by Lyal [51] to a distinct genus, Bisonicola [9]. Further data were only provided by studies from the 1970s [24,25], which confirmed the occurrence of chewing lice and the tick I. ricinus in a wild herd from the Białowieża Forest. Comprehensive research conducted since the 1990s revealed further parasitic arthropods, the list of which includes 15 species (Table 2). Later long-term research enabled the determination of the infestation parameters for the European bison, including the age and sex structure, the dynamics of occurrence, and changes in the population structure of individual species; it also analyzed the topography of parasites in the host, their tissue location, and the possible infestation symptoms, which shed new light on the problems of topical specificity. A comparison of infestation in European bison from different herds in the Białowieża Forest with those from other regions of Poland, and from wild and captive herds, highlighted the important role played by environmental conditions on ectoparasite infestation [6-8,32,34]. Moreover, new mite species were described and discovered, i.e., Demodex bisonianus and D. bialoviensis [19,33].

The parasitic arthropod fauna of the European bison includes taxa specific to this host (monoxenic), as well as those typical of the European bison and other ungulates (oligoxenic), and those typical for the European bison, which are common in other hosts (polyxenic); it also includes parasites present in the same type of environment or geographic region, as well as those observed sporadically or accidentally. The specific parasitofauna of the European bison is limited to four species, of which three are arthropods (B. sedecimdecemrii, D. bisonianus, D. bialoviensis), and the other, Trypanosoma wrublewski, is a flagellate. Both the chewing lice and the demodecid mites are common parasites, and have been recorded in European bison from different populations; however, the infestation intensity is typically low, and its course is asymptomatic. Only B. sedecimdecembrii sometimes form more numerous, local clusters (nests), accompanied by local dermal abnormalities (Figure 5). These chewing lice can also accumulate in the areas where different lesions are already present, thus providing better access to food. In rare cases, they exhibit mass occurrences, resulting in mallophagosis $[9,38]$. The role of chewing lice in pathogen transmission is rather limited, due to their keratophagous mode of feeding, which typically involves no contact with blood, and the minor exchange of parasites between the hosts.

The skin mites of the family Psoroptidae are typical ungulate parasites (oligoxenic), and exhibit a variable incidence rate in the European bison. One of the predominant parasitic arthropod species in the European bison is Ch. bovis (Figure 3), recorded frequently in both free-living and captive herds. It often causes local or more extensive skin lesions (chorioptosis), mainly in the area of the fetlocks, abdomen, and sides, up to the neck area. However, the parasitosis differs from that of the chorioptosis of other ungulates. Phalacrosis or scabs occur rarely in the European bison, and a mass presence of $\mathrm{Ch}$. bovis is manifested by the presence of fine, light exfoliations (similar to dandruff), which can present as yellowish flakes in intense cases, hidden by the rich hair cover [8,36]. Psoroptes equi is an accidental parasite among European bison [8,37]. 
(a)

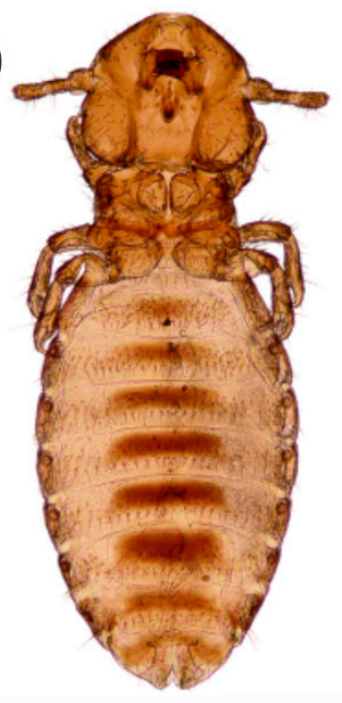

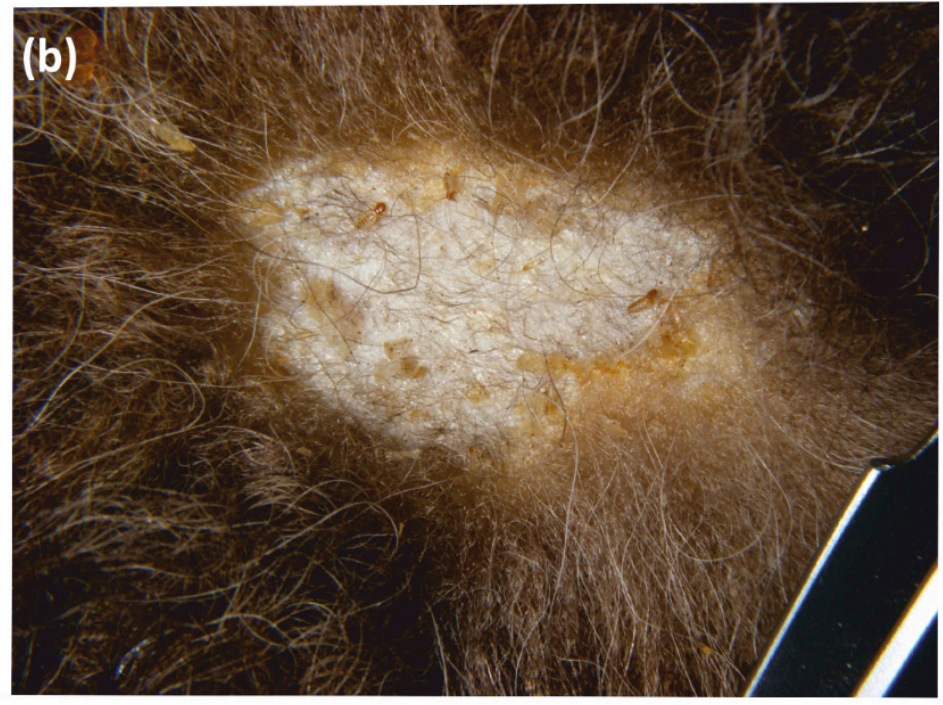

Figure 5. Bisonicola sedecimdecemrii: (a) Female; (b) Mallophagosis-cluster (nest) of chewing lice in the winter season.

In contrast, the ticks of the Ixodidae have a wide host circle associated with different habitat types and geographic regions, and are typical for the European bison. Four species have been recorded from this species, of which two (I. ricinus, D. reticulatus) are common. Ixodes persulcatus is recorded sporadically (only in the Białowieża Forest), while I. hexagonus is an accidental record, from breeding facility conditions [6,22]. Ixodes ricinus, the most important and most common of the European tick species, occurs in the European bison in different regions, throughout the year, but it exhibits variable seasonal dynamics and population structure. Importantly, females are clearly dominant in the ticks xenopulation in Białowieża bison; during this stage, the parasite repeatedly has relatively long contact with other hosts, which creates a greater possibility of pathogen transmission; not only between individuals within the same population, but also between populations of different species of mammals, birds, or even reptiles. This is more so that I. ricinus is a polyxenic parasite with an extremely wide host circle; it has been recorded in nearly 300 species of terrestrial vertebrates [52-55].

The second tick species recorded regularly in the European bison from the Białowieża Forest is the ornate cow tick $D$. reticulatus. This tick species has been found in different regions of Europe, including Poland, but it is particularly common in the north-east part of the country. This parasite is associated mainly with large ungulate mammals: in other regions, the adult stages are recorded mainly in deer and elk Alces alces (Linnaeus, 1758) $[56,57]$. This tick has been regularly recorded in European bison since the 1990s; it was found in up to $90 \%$ of the Białowieża population, but only in the winter season, when the only examples were non-fed individuals wintering on the hosts [5,22,27,29]. Outside of the winter season, D. reticulatus have been also found in autumn, and these were fed females [22]. No D. reticulatus have been found in the European bison individuals studied in the summer season in the present study.

Sporadic parasites include the fly L. cervi, and the itch mite S. scabiei. Lipoptena cervi is a widely distributed Eurasian species, and a typical parasite of deer. It has mass appearances in autumn. Following this time, it is regularly observed in European bison, but it is not as numerous as in deer $[25,34]$. In turn, S. scabiei, a polyxenic parasite noted in numerous mammal species, where it can cause sarcoptosis, has been observed in European bison at low numbers, in only some host individuals [8,34].

To sum up, studies carried out at different times of the year on European bison from free-living (wild) populations, breeding facilities, and zoological gardens, indicate that parasitic arthropods are common in the species. However, the species composition of the parasitofauna and the level of infection (intensity of infestation, density, prevalence) 
depend on many factors, including the season (e.g., hematophagous flies, ticks, or chewing lice showing clear seasonal dynamics), the geographic locality (local parasites), or the condition of the hosts (high intensity or increased symptoms of parasitosis are usually visible in European bison with worse condition, worse health).

The symptoms of infection, i.e., parasitosis, usually occur at high infestation intensity parameters; so far, two types of parasitosis caused by arthropods have been reported: mallophagosis (sporadically) and chorioptosis. Infestations often have an asymptomatic nature, especially in the case of specific parasites. However, the continuous activity of the arthropods penetrating the skin of the European bison creates a gateway for infections (such as itch mite, chewing lice, ticks), or pathogen transmission (ticks, hematophagous flies). In warmer periods of the year, European bison are subject to massive attacks by ticks or hematophagous flies, which are not only troublesome parasites, but also vectors of a number of pathogenic microorganisms (e.g., [28]). It appears that parasites which occur in both European bison populations and those of other mammals (albeit with a different intensity), such as ticks, have a significant effect on bison health, and this can affect both sexes, and various age groups. Studies confirm the presence of pathogenic microorganisms in European bison [28,58,59], the typical vectors of which are ticks, e.g., Coxiella burnetii (transmitted e.g., by I. ricinus, I. persucatus, D. reticulatus), and these are known to cause abortions and stillbirth in ungulates [60].

\section{Conclusions}

So far, 15 species of parasitic arthropods have been shown in bison, with a different range of relationships with the hosts, from specific and typical parasites, to sporadic and accidental parasites. New data indicate that the list is not yet complete and that the individual parasite-host systems are insufficiently understood. To ensure the successful conservation of the European bison as a species, it is necessary to understand the nature of the parasitic arthropods known to affect them, including their species and geographic diversity, full seasonal dynamics, infection routes, and the relationship in the host-parasite system, and to conduct constant parasitological monitoring. This need is reinforced by the fact that the natural habitats of the European bison remain under increasing pressure, and there is a need to transfer the individual bison to other regions of Europe; this can result in the acquisition of new, alien parasites by the bison themselves, of the transfer of their own parasites, which may pose a threat to the fauna in the new environment [61].

Author Contributions: Conceptualization, J.N.I., L.R., W.B.; Sampling, J.N.I., L.R., W.B.; Microscopy Analysis, J.N.I. and L.R.; Data Analysis, J.N.I., L.R., W.B.; Writing-Original Draft Preparation, J.N.I., L.R., W.B.; Writing, Review and Editing J.N.I., L.R., W.B. All authors have read and agreed to the published version of the manuscript.

Funding: This research received no external funding.

Institutional Review Board Statement: Ethical review and approval were waived for this study, due to the use of only dead animals.

Informed Consent Statement: Not applicable.

Data Availability Statement: No new data were created or analyzed in this study. Data sharing is not applicable to this article.

Conflicts of Interest: The authors declare no conflict of interest.

\section{References}

1. Izdebska, J.N. Stawonogi Pasożytnicze Żubra w Świetle Restytucji. In Rola Hodowli Ex Situ w Procesie Restytucji Żubra; Olech, W., Ed.; O. K. L.: Gołuchów, Poland, 2007; pp. 6-11.

2. Karbowiak, G.; Demiaszkiewicz, A.W.; Pyziel, A.M.; Wita, I.; Moskwa, B.; Werszko, J.; Bien, J.; Gozdzik, K.; Lachowicz, J.; Cabaj, W. The parasitic fauna of the European bison (Bison bonasus) (Linnaeus, 1758) and their impact on the conservation. Part 1. The summarising list of parasites noted. Acta Parasitol. 2014, 59, 363-371. [CrossRef] [PubMed]

3. Raczyński, J. (Ed.) European Bison Pedigree Book 2020; Białowieża National Park: Białowieża, Poland, 2020. 
4. European Bison Friends Society. Available online: https://smz.waw.pl/baza_wiedzy/mapa-wystepowania-zubra/ (accessed on 17 December 2021).

5. Izdebska, J.N. Występowanie Dermacentor reticulatus (Acari, Ixodidae) u żubra (Bison bonasus) z Puszczy Białowieskiej. Prz. Zool. 1998, 42, 219-221.

6. Izdebska, J.N. European bison arthropod parasites from closed Polish breeding facilities. Acta Parasitol. 2001, 46, 135-137.

7. Izdebska, J.N. The occurrence of parasitic arthropods in two groups of European bison in the Białowieża Primeval Forest. Wiad. Parazytol. 2001, 47, 801-804. [PubMed]

8. Izdebska, J.N. Skin mites (Acari: Demodecidae, Psoroptidae and Sarcoptidae) of the European bison, Bison bonasus. Biol. Lett. 2006, 43, 169-174.

9. Izdebska, J.N. Bisonicola sedecimdecembrii (Phthiraptera: Trichodectidae) from European bison-Redescription of adults and description of juvenile stages. Entomol. Fenn. 2011, 22, 69-77. [CrossRef]

10. State Forests. Available online: https:/ / www.lasy.gov.pl/en (accessed on 15 December 2021).

11. Kadulski, S.; Izdebska, J.N. Methods Used in Studies of Parasitic Arthropods in Mammals. In Arthropods. Epidemiological Importance; Buczek, A., Błaszak, C., Eds.; Kliber: Lublin, Poland, 2006; pp. 113-118.

12. Izdebska, J.N. Demodex spp. (Acari: Demodecidae) in brown rat (Rodentia: Muridae) in Poland. Wiad. Parazytol. 2004, 50, 333-335. [PubMed]

13. Klompen, J.S.H. Phylogenetic Relationships in the Mite Family Sarcoptidae (Acari: Astigmata); Miscellaneous publications, No. 180, Museum of Zoology; University of Michigan: Ann Arbor, MI, USA, 1992; pp. 1-154.

14. Siuda, K. Kleszcze Polski (Acari: Ixodida). Część II. Systematyka i Rozmieszczenie; Polskie Towarzystwo Parazytologiczne: Warszawa, Poland, 1993.

15. Borowiec, L. Klucze do Oznaczania Owadów Polski. Cz. XXVIII Diptera, z. 77—Wpleszczowate-Hippoboscidae; Państwowe Wydawnictwo Naukowe: Warszawa, Poland, 1984

16. Wilson, D.E.; Reeder, D.M. (Eds.) Mammals Species of the World. A Taxonomic and Geographic Reference, 3rd ed.; The Johns Hopkins University Press: Baltimore, MD, USA, 2005. Available online: http://www.departments.bucknell.edu/biology/resources/msw3 (accessed on 15 December 2021).

17. Integrated Taxonomic Information System (ITIS). Available online: http:/ / www.itis.gov (accessed on 15 December 2021).

18. Margolis, L.; Esch, G.W.; Holmes, J.C.; Kuris, A.M.; Schad, G.A. The use of ecological terms in parasitology (report of an ad hoc committee of the American Society of Parasitologists). J. Parasitol. 1982, 68, 131-133. [CrossRef]

19. Izdebska, J.N.; Rolbiecki, L.; Bielecki, W. Demodex bialoviensis sp. nov. (Acariformes, Demodecidae) a new, specific parasite of the European bison Bison bonasus (Artiodactyla, Bovidae). Int. J. Parasitol. Parasites Wildl. 2022, 17, 138-143. [CrossRef]

20. Kadulski, S.; Izdebska, J.N.; Kończyk, M. Stawonogi pasożytnicze żubra Bison bonasus z Puszczy Białowieskiej. Wiad. Parazytol. 1996, 42, 255-260.

21. Izdebska, J.N.; Rolbiecki, L. Przystosowania do Pasożytnictwa i Lokalizacja Roztoczy Pasożytniczych w Skórze Żubra. In Perspektywy Rozwoju Populacji Żubrów; Olech, W., Ed.; Artisco: Goczałkowice-Zdrój, Poland, 2006; pp. 109-114.

22. Izdebska, J.N. Obserwacje Lokalizacji Kleszczy (Acari, Ixodidae) u Żubrów (Bison bonasus) w Polsce. In Stawonogi. Interakcje Pasożyt-Żywiciel; Buczek, A., Błaszak, C., Eds.; Liber: Lublin, Poland, 2004; pp. 45-51.

23. Arzamasov, I. Ixodovye Klešči; Izdatelstvo AN Belaruskiej SSR: Minsk, Belarus, 1961.

24. Kadulski, S. Pasożyty zewnętrzne żubra Bison bonasus (L.) z Puszczy Białowieskiej. Wiad. Parazytol. 1977, 23, 227-229. [PubMed]

25. Kadulski, S. Występowanie Stawonogów Pasożytniczych na Łownych Lagomorpha i Artiodactyla—Próba Syntezy; Zeszyty Naukowe Uniwersytetu Gdańskiego. Rozprawy i Monografie: Gdańsk, Poland, 1989; Volume 132, pp. 1-140.

26. Kiziewicz, B. Zoosporic microorganisms isolated from Dermacentor reticulatus F. ticks found in surface waters of the Białowieża National Park. Pol. J. Environ. Stud. 2005, 14, 691-698.

27. Karbowiak, K.; Izdebska, J.N.; Czaplińska, U.; Wita, I. Przypadki Zimowania Kleszczy z Rodziny Ixodidae na Żywicielach w Puszczy Białowieskiej. In Stawonogi i Żywiciele; Buczek, A., Błaszak, C., Eds.; Liber: Lublin, Poland, $2003 ;$ pp. 77-82.

28. Matsumoto, K.; Grzeszczuk, A.; Brouqui, P.; Raoult, D. Rickettsia raoultii and Anaplasma phagocytophilum in Dermacentor reticulatus ticks collected from Bialowieza Primeval Forest European bison (Bison bonasus bonasus), Poland. Clin. Microbiol. Infect. 2009, 15 (Suppl. 2), 286-287. [CrossRef] [PubMed]

29. Mierzejewska, E.J.; Welc-Faleciak, R.; Karbowiak, G.; Kowalec, M.; Behnke, J.M.; Bajer, A. Dominance of Dermacentor reticulatus over Ixodes ricinus (Ixodidae) on livestock, companion animals and wild ruminants in eastern and central Poland. Exp. Appl. Acarol. 2015, 66, 83-101. [CrossRef]

30. Biernat, B.; Karbowiak, G.; Stańczak, J.; Masny, A.; Werszko, J. The first detection of the tick-borne encephalitis virus (TBEV) RNA in Dermacentor reticulatus ticks collected from the lowland European bison (Bison bonasus bonasus L.). Acta Parasitol. 2016, 61, 130-135. [CrossRef] [PubMed]

31. Paulauskas, A.; Aleksandravičienè, A.; Lipatova, I.; Griciuvienė, L.; Kibiša, A.; Žukauskienė, J.; Radzijevskaja, J. Molecular detection of Babesia spp. in European bison (Bison bonasus) and their ticks. Ticks Tick Borne Dis. 2021, 12, 101807. [CrossRef] [PubMed] 
32. Izdebska, J.N. Stawonogi pasożytnicze żubrów z Bieszczad. Sci. Messenger Lviv State Acad. Vet. Med. Named S.Z. Gzhytskyj 2001, 3, 208-211.

33. Kadulski, S.; Izdebska, J.N. Demodex bisonianus sp. nov. (Acari, Demodicidae) a new parasite of the bison (Bison bonasus L.). Wiad. Parazytol. 1996, 42, 103-110. [PubMed]

34. Izdebska, J.N. Porównanie Infestacji Stawonogami Pasożytniczymi Żubrów ze Stad Wolnych i Hodowli w Polsce. In Ochrona Żubrów Zachodniopomorskich; Olech, W., Ed.; ZODR: Ińsko, Poland, 2005; pp. 38-42.

35. Demiaszkiewicz, A.W. Przypadek świerzbu naskórnego u żubra Bison bonasus (L) w Puszczy Białowieskiej. Med. Weter. 1988, 44, 547-548.

36. Izdebska, J.N. Chorioptes Bovis (Acari, Psoroptidae) in Polish Bison: Asymptomatic Infestation? In Proceedings of the Conference European Bison Conservation; Krasińska, M., Daleszczyk, K., Eds.; Mammals Research Institute PAS: Białowieża, Poland, 2004; pp. 54-57.

37. Izdebska, J.N.; Cydzik, K. Świerzbowiec Naskórny-Rzadki Pasożyt Żubra. In Ochrona Żubrów Zachodniopomorskich; Olech, W., Ed.; ZODR: Barzkowice, Poland, 2005; pp. 43-45.

38. Izdebska, J.N. Bisonicola sedecimdecembrii (Mallophaga, Trichodectidae)—Wszoł, Który Przetrwał? In Stawonogi i Żywiciele; Buczek, A., Błaszak, C., Eds.; Liber: Lublin, Poland, 2003; pp. 105-115.

39. Eichler, W. Ein Haarling beim Wisent. Berl. Munch. Tierarztl. Wochenschr. 1946, 44, 3525.

40. Złotorzycka, J. Klucze do Oznaczania Owadów Polski. Cz. XV, Wszoły—Mallophaga, z. 3-Nadrodziny Goniodoidea i Trichodectoidea; Państwowe Wydawnictwo Naukowe: Warszawa, Poland, 1972.

41. Wróblewski, K. Żubr Puszczy Białowieskiej: Monografia; Wydawnictwo Polskie: Poznań, Poland, 1927.

42. Heptner, V.G.; Nasimovich, A.A.; Bannikov, A.G. Mammals of the Soviet Union; Amerind Publishing: New Delhi, India, 1988.

43. Piusiński, W.; Malicka, E.; Bielecki, W.; Osińska, B.; Lenartowicz-Kubrat, Z. Zmiany patomorfologiczne u żubrów w Puszczy Białowieskiej. Med. Weter. 1996, 52, 386-388.

44. Piusińiski, W.; Bielecki, W.; Malicka, E.; Kita, J.; Dziąba, K.; Osińska, B.; Anusz, K.; Kowalski, B.; Lenartowicz-Kubrat, Z. Patomorfologia i patogeneza schorzenia narządu płciowego (napletka i prącia) żubrów w Puszczy Białowieskiej. Med. Weter. 1997, 53, 598-600.

45. Krzysiak, M.K.; Dackiewicz, J.; Kęsik-Maliszewska, J.; Larska, M. Post-mortem evaluation of pathological lesion in European bison (Bison bonasus) in the Białowieża Primeval Forest between 2008 and 2013. Bull. Vet. Inst. Pulawy 2014, 58, 421-431. [CrossRef]

46. Rzewuska, M.; Rodo, A.; Bielecki, W. Dermacentor reticulatus ticks as pissible vector of Trueperella pyogenes infection in European bison (Bison bonasus): Preliminary studies. J. Comp. Pathol. 2016, 154, 120. [CrossRef]

47. Izdebska, J.N.; Rolbiecki, L. The Biodiversity of Demodecid Mites (Acariformes: Prostigmata), specific parasites of mammals with a global checklist and a new finding for Demodex sciurinus. Diversity 2020, 12, 261. [CrossRef]

48. Izdebska, J.N.; Rolbiecki, L. An Analysis of Symptoms of Parasitic Arthropod Infestation on Bison Skin. In Proceedings of the Conference European Bison Conservation; Krasińska, M., Daleszczyk, K., Eds.; Mammals Research Institute PAS, Centre of Excellence BIOTER: Białowieża, Poland, 2004; pp. 58-61.

49. Izdebska, J.N.; Cydzik, K. Analysis of the reasons for differences in topical specificity among various species of tick (Acari, Ixodidae) infesting European bison. Eur. Bison Conserv. News. 2010, 3, 75-84.

50. Cayol, C.; Koskela, E.; Mappes, T.; Siukkola, A.; Kallio, E.R. Temporal dynamics of the tick Ixodes ricinus in northern Europe: Epidemiological implications. Parasit. Vectors 2017, 10, 166. [CrossRef] [PubMed]

51. Lyal, C.H.C. A cladistic analysis and classification of trichodectid mammal lice (Phthiraptera, Ischnocera). Bull. Br. Mus. Nat. Hist. 1985, 51, 187-346.

52. Schwarz, A.; Maier, W.A.; Kistemann, T.; Kampen, H. Analysis of the distribution of the tick Ixodes ricinus L. (Acari: Ixodidae) in a nature reserve of western Germany using Geographic Information Systems. Int. J. Hyg. Environ. Health 2009, 212, 87-96. [CrossRef]

53. Gern, L.; Humair, P.F. Ecology of Borrelia burgdorferi sensu lato in Europe. In Lyme Borreliosis: Biology, Epidemiology and Control; Gray, J.S., Kahl, O., Lane, R.S., Stanek, G., Eds.; CAB International: Wallingford, UK, 2002; pp. 141-174.

54. Nowak-Chmura, M. Fauna Kleszczy (Ixodida) Europy Środkowej; Wydawnictwo Naukowe Uniwersytetu Pedagogicznego: Kraków, Poland, 2013.

55. Herrmann, C.; Gern, L. Search for blood or water is influenced by Borrelia burgdorferi in Ixodes ricinus. Parasit. Vectors 2015, 8, 6. [CrossRef]

56. Kadulski, S. Dalsze badania nad stawonogami pasożytniczymi łosia Alces alces w Polsce. Wiad. Parazytol. 1996, 42, $349-355$.

57. Cydzik, K.; Kadulski, S. Parasitic Insects of the Red Deer (Cervus elaphus L.) in the Northern Poland. In Arthropods. Invasions and their Control; Buczek, A., Błaszak, C., Eds.; Akapit: Lublin, Poland, 2009; pp. 59-66.

58. Adaszek, Ł.; Dzięgiel, B.; Krzysiak, M.; Skrzypczak, M.; Adaszek, M.; Staniec, M.; Wyłupek, D.; Winiarczyk, S. Detection of Borrelia burgdorferi sensu lato DNA in the blood of wild bison from Białowieza Primeval Forest in eastern Poland. Pol. J. Vet. Sci. 2014, 17, 713-715. [CrossRef] [PubMed]

59. Karbowiak, G.; Víchová, B.; Werszko, J.; Demiaszkiewicz, A.W.; Pyziel, A.M.; Sytykiewicz, H.; Szewczyk, T.; Pet'ko, B. The infection of reintroduced ruminants-Bison bonasus and Alces alces-with Anaplasma phagocytophilum in northern Poland. Acta Parasitol. 2015, 60, 645-648. [CrossRef] [PubMed] 
60. Didkowska, A.; Klich, D.; Hapanowicz, A.; Orłowska, B.; Gałązka, M.; Rzewuska, M.; Olech, W.; Anusz, K. Pathogens with potential impact on reproduction in captive and free-ranging European bison (Bison bonasus) in Poland-A serological survey. BMC Vet. Res. 2021, 17, 345. [CrossRef] [PubMed]

61. Jørgensen, D. Conservation implications of parasite co-reintroduction. Conserv. Biol. 2015, 29, 602-604. [CrossRef] [PubMed] 